\title{
Resource Potentials of Composting the Organic Wastes Stream from Municipal Solid Wastes Compositions Arising in
} Nigerian Cities

\author{
Adamu Isa Harir ${ }^{*}$, Rozilah Kasim², Bala Ishiyaku1 \\ ${ }^{1}$ Faculty of Environmental Technology, Abubakar Tafawa Balewa University, Bauchi, Nigeria \\ ${ }^{2}$ Faculty of Technology Management, Business and Entrepreneurship, University Tun Hussein Onn Malaysia \\ (UTHM), Johor, Malaysia \\ Email: "adamuharir@gmail.com, rozilah@uthm.edu.my, balaishiyaku@yahoo.com
}

Received 4 March 2015; accepted 6 June 2015; published 10 June 2015

Copyright (C) 2015 by authors and Scientific Research Publishing Inc.

This work is licensed under the Creative Commons Attribution International License (CC BY). http://creativecommons.org/licenses/by/4.0/

(c) (i) Open Access

\section{Abstract}

The paper presented an assessment of the resource potentials of composting organic waste materials arising from the municipal solid waste stream from cities in Nigeria. Through a review of quantitative data, the composition of municipal solid waste arising within cities in Nigeria was examined in order to identify the potentials for composting organic materials from the waste stream composition. The data showed that the average majority of the waste stream was organic materials which implied high potentials for composting organic waste materials from Nigerian cities. The review also identified further potentials for composting was associated with the large population and the majority of them engaged in agriculture, as a high potential market for compost manure in Nigeria. There were more potentials derivable from the current policies of importing and supplying chemical fertilizer with huge subsidies for domestic agriculture in the country. The need to substitute these policies of chemical fertilizer with the use of compost manure implied high potentials for composting in the country. The paper also identified numerous benefits of composting in general and with particular reference to the Nigerian situation which includes, among others a reduction of the vast quantity of solid waste for final disposal, reducing air pollution and ground water leachate and also employment generation and increased income. Therefore, the paper recommended a deliberate government policy to promote composting of organic solid wastes material and marketing of compost manure to substitute the current policies of importing chemical fertilizer with subsidy for domestic agriculture as a strategy to achieve sustainable waste management in Nigeria.

\footnotetext{
${ }^{*}$ Corresponding author.
}

How to cite this paper: Harir, A.I., Kasim, R. and Ishiyaku, B. (2015) Resource Potentials of Composting the Organic Wastes Stream from Municipal Solid Wastes Compositions Arising in Nigerian Cities. Journal of Geoscience and Environment Protection, 3, 10-15. http://dx.doi.org/10.4236/gep.2015.34002 


\section{Keywords}

\section{Composting, Organic Wastes, Waste Composition, Sustainable Waste Management, Resource Potentials}

\section{Introduction}

Rapidity of population, urbanisation and economic growths has increased solid waste generation rates and material composition (Guerrero, Maas \& Hogland, 2013 in [1]. Finding sustainable option of solid waste disposal remains a major challenge to waste management industry (Farrell \& Jones, 2009 in [2]. Thus, in Nigeria and most developing countries, authorities are facing the challenges to determine the appropriate option among alternative policies for sustainable solid waste management in cities. Many authors, [3] [4] opined that the solid composition was very essential to determine appropriate policy option for solid waste management in any city. Thus, the waste material composition analysis is necessary to determine the choice of appropriate policy for solid waste management in Nigerian cities.

Municipal solid wastes consist of discarded items such as food wastes, containers, product packaging and other miscellaneous wastes, from residential, commercial, electronic institutional and industrial sources [5] while municipal solid waste management refers to the collection, transfer, treatment, recycling, resource recovery and disposal of solid wastes from urban areas [6]. [7] cited municipal solid waste management as a global challenge, especially in developing countries due to its adverse environmental effects. In these countries, heaps of solid wastes are a common sight view in many locations within the city landscape. More so cities in developing countries spend $20 \%$ - $50 \%$ of their annual budget on solid waste management, but waste collection services cover less than $50 \%$ of the population in these cities [8] [9]. Therefore, high public expenditure with a low performance of service delivery is affecting waste management in developing countries like Nigeria.

In response to the shortcomings of the current solid waste management, many countries initiate environmental reforms with remarkable advances in sustainable solid waste management [10]. As Yuan et al. (2006) in [11] stated that Germany, Sweden, Japan and the United States had achieved remarkable success in waste recycling. In Nigeria, policies on recycling are virtually absent and composting is not formally integrated into urban solid waste management, even though about $60 \%$ of the municipal solid waste stream compositions are compostable organic materials. Therefore, there is a need to assess the resource potentials of composting organic solid wastes as a strategy for sustainable waste management in Nigeria.

\section{The Benefits of Composting Organic Materials from Municipal Solid Wastes}

Composting is the biological decomposition process of organic waste materials such as food waste, manure, leaves, grass trimmings papers into an extremely useful humus substance by various micro-organisms, including bacteria and fungi in the presence of oxygen and $\mathrm{PH}$ [6]. Waste composting reduces the quantity of generated waste to be disposed and subsequently minimizes air pollution arising from landfills and open dumps which are known as the major sources of greenhouse gas [12]. According to Saft and Elsinga, (2006) in [13] anaerobic digestion of organic wastes produces methane $\left(\mathrm{MH}_{4}\right)$ and carbon dioxide $\left(\mathrm{CO}_{2}\right)$. Composting can reduce GHG emissions by reducing the quantity of virgin waste material being disposed into the landfills and by implication minimizes anaerobic digestion and the production of $\mathrm{MH}_{4}$ and $\mathrm{CO}_{2}$. Similarly, Adani et al. (2004) in [14] observed that waste composting produces lower GHG emissions by about $82 \%$ less than waste disposal in landfills. Therefore, waste composting is relevant in the effort to reduce GHG emissions in Nigeria.

Composting can reduce air pollution and ground water leachates. The conversion of organic waste into nutrient stable compost can reduce the quantities of waste for ultimate disposal in landfill and also reduce water pollution through substitution of chemical fertilizers with compost manure in urban agriculture [15]. A study of urban agriculture in Harare (Kisner, 2008 in [15] reported the practices of chemical fertilizers in agriculture had induced ground water pollution through eutrophication and leaching and it was recommended that the use of compost manure as a substitute will mitigate the pollution effects. Similarly, [5] observed that leachates from improper handling of urban solid wastes contributed to the high presence of elements in groundwater around 
Andhrapradesh, area of India.

Compost manure can enhance soil remediation and stabilises the ecosystem. [16] also cited that compost manure can restore nutrients in soils and maintain the sustainability of ecosystems. Similarly, [14] observed that organic wastes are useful in land remediation and restoration because the compost manure can ameliorate soils which are polluted with heavy metals or acidic substances. In another narration, [17] stated that the use of composting for bioremediation of contaminated soil has gained much ground in many developed countries of the world. These views were further corroborated by research findings in Europe by [18] which showed organic farming have a general positive impacts on the environment and also organic farms tend to have higher soil organic matter content and lower nutrient losses such as nitrogen leaching, and emissions of nitrous oxide and ammonia per unit area.

Meanwhile, composting can also reduce the mass of solid wastes by about 20\% to 40\% (Omran et al., 2007 in [14] Solid waste composting reduces the quantity of waste for ultimate disposal leading to lower operating costs. These operating costs, which include collection, transportation and disposal, are more than half the total expenditure on waste management in developing countries [9]. Due to the high cost of collection and disposal in the total waste management budget in developing countries, recovering the organic waste fractions through composting will have significant impact on cost reduction and consequently on achieving sustainable waste management. Furthermore, composting the large fractions of organic materials which is the average majority in the municipal solid waste stream in Nigerian cities will substantially minimise the quantities of solid waste generated and significantly reduce the total operating cost of waste management [19].

\section{Municipal Solid Waste Management in Nigeria}

Nigeria is one of the largest Country in Africa, South of the Sahara. It is located in the West African sub-region of the gulf of guinea with a total land area of $910,768 \mathrm{~km}^{2}$. Nigeria has a population of about 160 million with national average growth at $2.9 \%$ per annum while the urban growth rate is 5.5\% [20]. The country has a GDP per capita of $\$ 1800$ and population below poverty line is up to 60\% [6] which impacted significantly on solid waste management (Agunwamba, 1998 and Achankeng, 2003 in [10]. Thus, one of the challenges of urban centres in Nigeria is the inadequate infrastructure for service delivery including solid waste management.

In Nigeria as in most developing countries inefficient collection and disposal of solid waste were cited in many cities. [9] cited solid waste was among the three major environmental problems in Nigeria. Scholars like [21] citing Ayatamuno \& Gobo (2004) indicated that 35\% of households in Ibadan, 28\% in Port Harcourt, 33\% in Kaduna and 44\% in Enugu have no access to waste collection services. Similarly, Achi (1993) in [22] reported a country wide situation that between $25 \%$ - $40 \%$ of municipal solid waste is not collected in the urban centres in Nigeria. Consequently, solid wastes are disposed into the drainages, streams or valleys, roadsides and open spaces in many cities in the country.

In Nigeria, open dump sites are the most common facilities provided by public authorities for solid waste disposal. In major cities like Kano, Abuja, Lagos, Makurdi, Onitsha, Bauchi, Uyo and others in Nigeria, solid wastes are disposed in open dumps. Wastes deposited in the open dumps are neither processed nor treated, but are liable to scavengers and the rest are often set on an open fire in order to reduce the volume by burning while creating space to accommodate new arriving waste deposits. This waste disposal practice in Nigeria has no mitigation measures regarding impact on human life or the environment. Consequently, the open dumps constitute a potential health hazard to scavengers and the residence population within proximity locations. In addition the dump sites are sources of ground water pollution by leachates; agents of disease and infections; generate air pollution from smoke and foul odour emissions from decomposing waste. The assertions in these views were further corroborated by [12] in Kano City, Nigeria, that solid waste dump sites are sources of health hazards and GHG emission. In conclusion [12] recommended waste recycling as mitigation to the identified impacts of open dumping of solid waste. Thus, solid waste disposal in open dump sites is considered not sustainable in Nigeria. However, composting can reduce significantly the volume of organic material in the solid wastes stream [23] and by implication it can reduce the high cost of collection and disposal within the waste management system in Nigeria.

\section{Solid Wastes Composting in Nigeria}

Composting is sustainable in most developing countries due to its multiple benefits such as production of organ- 
ic manure, reduction of waste quantity for final disposal, reduced air pollution and ground water leachate and also employment and income creation. The practice of composting by households to dispose solid waste at home is a long standing tradition in Nigeria [24], in which many communities' household solid wastes like yam peels, banana leaves and maize combs were usually composted within the house and applied as manure in gardens and farms. However, this traditional system of home composting is inadequate to utilize the potentials in the huge quantities of organic solid wastes generated in Nigerian cities. For instance, Lewcock (1995) according to [10] has observed in Kano City, Nigeria, that the huge potentials for composting solid wastes has not been exploited, hence, he concluded that same situation may apply to many cities in Nigeria.

In Nigeria, agriculture engaged over $60 \%$ of the population and government import chemical fertilizer with subsidy rate up to $70 \%$ for domestic agriculture practices (New-Agriculturist, 2007 in [10]. This demand for chemical fertilizer can be converted to create a market for compost manure. However, it will require a deliberate government policy to increase public awareness about the negative impact of chemical fertilizer on the soil and also to promote compost production and marketing in the country. Production of compost manure will lower demand for chemical fertilizer and save foreign exchange and improve economic productivity in the country. The use of compost manure to substitute chemical fertilizer will also create employment and increase income in agriculture, which will alleviate poverty in Nigeria, where over $60 \%$ of the population lived below poverty level of USD1.00 per day [6]. It can also be implied that compost manure has a high potential market in Nigeria considering the large population with most people engaged in agriculture activities as earlier cited.

The review of quantitative data on solid wastes from cities across different regions in Nigeria showed the dominant compositions of organic materials. Literature showed that waste compositions in the cities of Port Harcourt [25] and Uyo [26] are about $66 \%$ and $74 \%$ organic materials, respectively. Similarly, [27] in Lagos city and [28] in Makurdi city also showed organic materials as the highest average majority of the municipal solid waste streams. In a more comprehensive summary of data on the compositions of municipal solid waste streams in cities across Nigeria (Table 1) [6] showed that the organic materials are the highest with a mean of 49.78\%, followed by paper $12.79 \%$ compared to plastics, metal, glass, textiles and other materials, respectively. These organic waste and papers constituted the compostable materials which is about $63 \%$ of the total waste stream in Nigerian cities. Many studies [27] [29], have also identified several benefits of composting to the Nigerian economy. However, government policy initiatives to encourage solid waste composting are virtually absent in Nigeria (Kofoworola, 2007 in [10].

\section{The Resource Potentials of Composting Organic Waste Stream in Nigerian Cities}

The data in Table 1 showed that the compostable waste fractions constituted the majority about $63 \%$ of the average waste stream in Nigerian cities. This indicates high resource potentials for composting in the country. However, while composting is most appropriate for organic materials and papers from the waste stream, others like plastic, metals and glasses are best disposed by recycling. Further potential is identified with the need for a policy on compost manure to replace the imported chemical fertilizer used for agriculture practices to reduce costs and pollution effect. In addition, other potentials are also due with the numerous benefits of composting

Table 1. Municipal solid waste composition in Nigerian cities (adapted: Ogwueleka, 2009).

\begin{tabular}{|c|c|c|c|c|c|c|c|}
\hline Composition (\% kg) & Organic wastes $^{*}$ & Paper $^{*}$ & Plastic & Glass & Metal & Textile \& leather & Inert \& others \\
\hline Makurdi & 52.2 & 12.3 & 8.2 & 3.6 & 7.1 & 2.5 & 14 \\
\hline Abuja & 58.5 & 8 & 11.3 & 4.8 & 3.1 & - & 0.2 \\
\hline Maiduguri & 25.8 & 7.5 & 18.1 & 4.3 & 9.1 & 3.9 & 31.3 \\
\hline Kano & 43 & 17 & 4 & 2 & 5 & 7 & 22 \\
\hline Onitsha & 30.7 & 23.1 & 9.2 & 9.2 & 6.2 & 6.2 & 15.4 \\
\hline Nsukka & 56 & 13.8 & 8.4 & 2.5 & 6.8 & 3.1 & 9.4 \\
\hline Ibadan & 76 & 6.6 & 4 & 0.6 & 2.5 & 1.4 & 8.9 \\
\hline Lagos & 56 & 14 & 4 & 3 & 4 & - & 19 \\
\hline Mean & $49.78^{*}$ & $12.79^{*}$ & 8.4 & 3.75 & 5.48 & 3.01 & 15.03 \\
\hline
\end{tabular}

*Compostable waste fractions_-no data available. 
organic wastes in Nigeria which includes: reduced waste quantity for final disposal, reduced air pollution and ground water leachate and also employment generation and increased income. However, despite the high potentials and numerous benefits for composting the organic materials from the municipal waste stream in Nigerian cities, government initiatives to encourage solid waste composting are virtually absent in Nigeria (Kofoworola, 2007 in Ezeah, 2010).

\section{Conclusion and Recommendations}

The assessment in this paper concludes that high resource potentials exist for composting from the municipal solid waste stream in Nigerian cities due to the high fraction of organic materials in the solid waste stream composition. In addition, composting is the lowest costing with lowest technology required and it generates lowest pollution effects and more benefits to the environment and the economy when compared to the existing practices of waste disposal into open dumps in Nigerian cities. The high potentials and other benefits of composting organic waste such as a reduction of the quantity of waste for final disposal, reducing air pollution and ground water leachate and also employment generation and others presented in this paper will promote economic productivity and increase income in Nigeria. Therefore, the paper recommends a government policy to promote composting of organic solid waste materials and marketing of compost manure as a substitute to importing chemical fertilizer for domestic agriculture. This strategy will achieve sustainable waste management in Nigeria.

\section{References}

[1] Harir A.I., Kasim, R. and Ishiyaku, B. (2014) A Theoretical Framework for the Analysis of Residential Solid Wastes Generation and Composition in Bauchi Metropolis, Nigeria. Proceedings of the International Integrated Engineering Conference (IIEC), UTHM, Malaysia, 1-4 December 2014.

[2] Harir, A.I., Kasim, R. and Ishiyaku, B. (2015) Exploring the Resource Recovery Potentials of Municipal Solid Waste: A Review of Solid Wastes Composting in Developing Countries. International Journal of Scientific and Research Publications, 5, 8 p.

[3] Gomez, D.A., Wismer, S. and Lopez, A. (2011) Evaluating the Mexican Federal District's Integrated Solid Waste Management Programme. Waste Management \& Research, 29, 480-490. http://dx.doi.org/10.1177/0734242X10380493

[4] Dangi, M.B., Pretz, C.R., Urynowicz, M.A., Gerow, K.G. and Reddy, J.M. (2011) Municipal Solid Waste Generation in Kathmandu, Nepal. Journal of Environmental Management, 92, 240-249. http://dx.doi.org/10.1016/j.jenvman.2010.09.005

[5] Babu, N.V., Rao, P.J. and Prasad, I.V.R.K.V. (2013) Impact of Municipal Solid Waste on Groundwater in the Environs of Greater Visakhapatnam Municipal Corporation Area, Andhrapradesh, India. International Journal of Engineering Science Invention, 2, 2319-6276.

[6] Ogwueleka, T. (2009) Municipal Solid Waste Characteristics and Management in Nigeria. Iranian Journal of Environmental Health Science, 6, 173-180.

[7] Butu, A.W., Ageda, B.R. and Bichi, A.A. (2013) Environmental Impacts of Roadside Disposal of Municipal Solid Wastes in Karu, Nasarawa State. Nigeria International Journal of Environment and Pollution, 1, 1-19.

[8] Nzeadibe, T.C. and Ajaero, C.K. (2010) Informal Waste Recycling and Urban Governance in Nigeria: Some Experiences and Policy Implications. Handbook of Environmental Policy, 245-264.

[9] Kadafa, A.A., Latifah, A.M., Abdullah, H.S. and Sulaiman, W.A. (2013) A Comparative Assessment of the Municipal Solid Waste Management Services. Life Science Journal, 10.

[10] Ezeah, C. (2010) Analysis of Barriers and Success Factors Affecting the Adoption of Sustainable Management of Municipal Solid Waste in Abuja, Nigeria. A PhD Thesis of the University of Wolverhampton, Wolverhampton.

[11] Zhang, D.Q., Tan, S.K. and Gersberg, R.M. (2010) Municipal Solid Waste Management in China: Status, Problems and Challenges. Journal of Environmental Management, 91, 1623-1633. http://dx.doi.org/10.1016/j.jenvman.2010.03.012

[12] Nabegu, A.B. (2011) Solid Waste and Its Implications for Climate Change in Nigeria. Journal of Human Ecology, 34, 67-73.

[13] Batool, S.A. and Chuadhry, M.N. (2009) The Impact of Municipal Solid Waste Treatment Methods on Green House Gas Emissions in Lahore, Pakistan. Waste Management, 29, 63-69. http://dx.doi.org/10.1016/j.wasman.2008.01.013

[14] Farrell, M. and Jones, D.L. (2009) Critical Evaluation of Municipal Solid Waste Composting and Potential Compost 
Markets. Bioresource Technology, 100, 4301-4310. http://dx.doi.org/10.1016/j.biortech.2009.04.029

[15] Downmore, M., Shepherd, M., Andrew, M. and Daniel, N.B.J. (2011) Municipal Solid Waste (MSW) Management Challenges of Chinhoyi Town in Zimbabwe: Opportunities of Waste Reduction and Recycling. Journal of Sustainable Development in Africa, 13, 168-180.

[16] Singh, R.P., Singh, P., Araujo, A.S.F., Hakimi Ibrahim, M. and Sulaiman, O. (2011) Resources, Conservation and Recycling Management of Urban Solid Waste: Vermicomposting a Sustainable Option. Resources, Conservation \& Recycling, 55, 719-729. http://dx.doi.org/10.1016/j.resconrec.2011.02.005

[17] Taiwo, A.M. (2011) Composting as a Sustainable Waste Management Technique in Developing Countries. Journal of Environmental Science and Technology, 4, 93-102. http://dx.doi.org/10.3923/jest.2011.93.102

[18] Tuomisto, H.L., Hodge, I.D., Riordan, P. and Macdonald, D.W. (2012) Does Organic Farming Reduce Environmental Impacts?-A Meta-Analysis of European Research. Journal of Environmental Management, 112, 309-320. http://dx.doi.org/10.1016/j.jenvman.2012.08.018

[19] Matter, A., Dietschi, M. and Zurbrügg, C. (2013) Improving the Informal Recycling Sector through Segregation of Waste in the Household-The Case of Dhaka Bangladesh. Habitat International, 38, 150-156. http://dx.doi.org/10.1016/j.habitatint.2012.06.001

[20] National Population Commission (NPC) (2008) 2006 Population Census Figures. Abuja. http://www.population.gov.ng

[21] Ogbonna, D.N., Amangabara, G.T. and Ekere, T.O. (2007) Urban Solid Waste Generation in Port Harcourt Metropolis and Its Implications for Waste Management. Management of Environmental Quality: An International Journal, 18, 7188. http://dx.doi.org/10.1108/14777830710717730

[22] Babanyara, Y.Y. and Bogoro, A.G. (2011) Evacuation of Solid Waste in Residential Areas of Bauchi Metropolis, Nigeria. Journal of Environmental Sciences and Resource Management, 3.

[23] Guerrero, L.A., Maas, G. and Hogland, W. (2013) Solid Waste Management Challenges for Cities in Developing Countries. Waste Management, 33, 220-232. http://dx.doi.org/10.1016/j.wasman.2012.09.008

[24] Olowomeye, R. (1991) The Management of Solid Waste in Nigerian Cities. Garland Publishing Inc., New York, London.

[25] Igoni, A.H., Ayotamuno, M.J., Ogaji, S.O.T. and Probert, S.D. (2007) Municipal Solid-Waste in Port Harcourt, Nigeria. Applied Energy, 84, 664-670. http://dx.doi.org/10.1016/j.apenergy.2006.12.002

[26] John, N.M., Edem, S.O., Ndaeyo, N.U. and Ndon, B.A. (2006) Physical Composition of Municipal Solid Waste and Nutrient Contents of Its Organic Component in Uyo Municipality, Nigeria. Journal of Plant Nutrition, 29, 189-194. http://dx.doi.org/10.1080/01904160500464836

[27] Kofoworola, O.F. (2007) Recovery and Recycling Practices in Municipal Solid Waste Management in Lagos, Nigeria. Waste Management, 27, 1139-1143. http://dx.doi.org/10.1016/j.wasman.2006.05.006

[28] Sha'Ato, R., Aboho, S.Y., Oketunde, F.O., Eneji, I.S., Unazi, G. and Agwa, S. (2007) Survey of Solid Waste Generation and Composition in a Rapidly Growing Urban Area in Central Nigeria. Waste Management, 27, 352-358. http://dx.doi.org/10.1016/j.wasman.2006.02.008

[29] Afon, A.O. and Okewole, A. (2007) Estimating the Quantity of Solid Waste Generation in Oyo, Nigeria. Waste Management \& Research, 25, 371-379. http://dx.doi.org/10.1177/0734242X07078286 